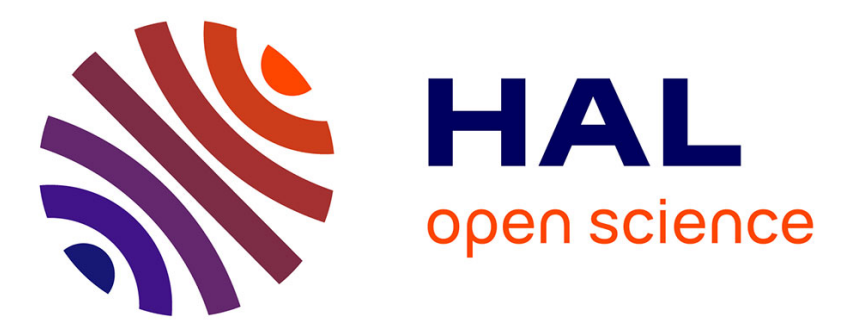

\title{
Immunocytochemical localization of Gn-RH (gonadotropin releasing hormone) systems in the brain of a marine teleost fish, the sole
} J. Núñez-Rodríguez, Olivier Kah, Bernard Breton, F. Le Menn

\section{- To cite this version:}

J. Núñez-Rodríguez, Olivier Kah, Bernard Breton, F. Le Menn. Immunocytochemical localization of Gn-RH (gonadotropin releasing hormone) systems in the brain of a marine teleost fish, the sole. Experientia, 1985, 41 (12), pp.1574 - 1576. 10.1007/BF01964814 . hal-01602190

\author{
HAL Id: hal-01602190 \\ https://hal.science/hal-01602190
}

Submitted on 2 Jun 2020

HAL is a multi-disciplinary open access archive for the deposit and dissemination of scientific research documents, whether they are published or not. The documents may come from teaching and research institutions in France or abroad, or from public or private research centers.
L'archive ouverte pluridisciplinaire HAL, est destinée au dépôt et à la diffusion de documents scientifiques de niveau recherche, publiés ou non, émanant des établissements d'enseignement et de recherche français ou étrangers, des laboratoires publics ou privés.

\section{다(1)}

Distributed under a Creative Commons Attribution - ShareAlikel 4.0 International 


\title{
Immunocytochemical localization of GnRH (gonadotropin releasing hormone) systems in the brain of a marine teleost fish, the sole
}

\author{
J. Nunez Rodriguez, O. Kah, B. Breton and F. Le Menn
}

Laboratoire de Biologie marine, Université de Bordeaux I. F-33405 Talence Cedex (France), Laboratoire des Interactiuns Cellulaires. Université de Bordeaux I (France), and Laboratoire de Physiologic des poissons, INRA, Rennes (France), 7 February 1985

Summary. The GnRH system was studied in the brain of the sole by immunocytochemistry (peroxidase-antiperoxidase method) (PAP) using antibodies to synthetic salmon GnRH (s-GnRH). Two centers containing immunorcactive cell bodies were observed in the forebrain, one located at the junction between the olfactory bulbs and the telencephalon and the other in the preoptic area. Numerous immunoreactive fibers were found, especially in the telencephalon, hypothalamus, pituitary, optic tectum and retina. Key words. GnRII; immunocytochemistry; brain; fish; reproduction.

Our laboratory is involved in studying the reproductive biology of the sole, Solea solea L., in particular the neuroendocrine control of gonadotropin secretion through the gonadotropin releasing hormone (GnRII). A homologous radioimmunoassay (RIA) for salmon GnRH (s-GnRH) has recently been developed $^{1}$ for determination of the annual variations of brain and pituitary GnRH content in the sole. However, for a better interpretation of the results, an immunocytochemical study of the cerebral GnRH distribution appeared to be useful, and is described in this paper.
Material and methods. The soles were caught by trawling off the coast of Arcachon, with the oceanographic ship of the C.N.R.S. (Côte d'Aquilaine). On board, the fish were kept in a large tank of running seawater and transferred into aerated scawater tanks under a natural photoregime in the laboratory. Experiments were conducled on fourteen 2-year-old male and female fish. The fish were anesthetized with MS222 (SANDOZ), and the brains, pituitaries and retinae then removed and immersed in $4 \%$ formaldehyde in $0.1 \mathrm{M}$ phosphate buffer at $\mathrm{pH} 7.7$ for $1 \mathrm{~h}$ at $4^{\circ} \mathrm{C}$. After rinsing for $1 \mathrm{~h}$ in the same buffer the tissues wcre 
immersed in $12 \%$ sucrose phosphate buffer solution for $12 \mathrm{~h}$ at $4^{\circ} \mathrm{C}$ and then frozen. Serial transverse and longitudinal sections were incubated for $12 \mathrm{~h}$ at $4^{\circ} \mathrm{C}$ with the primary antibody diluted 1:1000 to 1:3000 in phosphate buffer and rinsed in the same buffer. The sections were placed for $2 \mathrm{~h}$ in swine IgG (DAKO, Denmark) diluted $1: 200$, and after rinsing the slides were incubated for $1 \mathrm{~h}$ in peroxidase-antiperoxidase complexes diluted 1:600 (DAKO, Denmark). The sections were then treated with a solution containing $0.025 \%$ of 3,3-diaminobenzidine tetrachloride (SIGMA) and $0.006 \%$ of hydrogen peroxide dissolved in $0.05 \mathrm{M}$ Tris hydrochloride buffer at $\mathrm{pH}$ 7.6. The specificity of the antiserum to synthetic s-GnRH had previously been lested in a radioimmunoassay (RIA) system ${ }^{1}$, Nunez Rodriguez (unpublished observations). Omission of one step of the reaction or replacement of the primary antiserum by rabbit normal serum confirms the specificity of the immunoreaction. Liquid phase absorption of the specific antiserum by synthetic s-GnRH led to the extinction of the reaction.

Results. Using the PAP mcthod, immunoreactive cell bodies were observed in two regions of the forebrain. The first is located medioventrally in the caudal part of the olfactory bulbs just beside the ventral telencephalon (figs 1 and 2). This group is formed by $15-20$ neurons (30-40 $\mu \mathrm{m}$ in diameter) from which numerous fibers travel rostrally in the olfactory bulbs. The caudal projection of this nucleus is not very obvious. The second group of immunopositive cell bodies is located in the ventrolateral parts of the preoptic region (figs 1 and 3). These cells emit dorsally numerous processes forming a large bundle running ventrocaudally above the optic tract (figs 1 and 5) into the ventral hypothalamus and the pituitary stalk. In the pituitary gland itself these fibers scatter in the neurohypophysis (figs 1 and 4). A large number of fibers is observed in the different areas of the telencephalon and diencephalon. A high density of immunoreactive fibers is found in the ventral hypothalamus without particular organization, except for those entering the pituitary stalk. The saccus vasculosus is also well inneryated by GnRH fibers originating from the ventroposterior hypothalamus. Extensive innervation by immunoreactive GnRH fibers is found in the optic tectum. They are located mainly in the stratum album griseum but are also to be found in the other layers. More caudally, fibers are found in the ventral area of the medulla oblongata but not in the cerebellum. Numerous fibers are observed in the retina (fig. 6) close to the bipolar and amacrine cells. Discussion. We detected two GnRH centers containing immunoreactive cell bodies in the brain of a marine teleost fish by using an antibody to synthetic salmon GnRH?. The specificity of this antiserum has previously been studied by RIA!

Radioimmunoassayable GnRH has been found in brain and pituitary extracts of the sole (Nuncz Rodriguez and Breton, unpublished data) and previous studies have suggested that the primary structure of GnRII in sole is identical to that of salmon'. Other authors have also demonstrated the structural identity of GnRII in different teleost species ${ }^{3}$. In the solc, the first nucleus is located in the caudal part of the olfactory bulbs and probably corresponds to the nucleus olfactoretinalis described in the platyfish ${ }^{4-6}$, where the relationship between this nucleus and both the olfactory system and the retina is demonstrated. The presence of GnRH in the retina of the sole suggests that a similar relationship exists in this species. By the use of LHRH antibodies $^{4} 7$ it has been demonstrated that the neurons of the second center do not form a well-defined nucleus but are scattered within the ventral preoptic area. Our studies showed that these perikarya project as far as the neurohypophysis via the ventrolateral hypothalamus. Similar observations have been reported in the platyfish ${ }^{4}$ and the goldfish ${ }^{3}$. Although the presence of immunoreactive fibers in the other cerebral areas has been described in the species studied ${ }^{4-8}$, their origin is not clear. Very little has so far been discovered concerning the functional significance of these phenomena. The nucleus olfactoretinalis has been described in the goldfish as an element of the nervus terminalis
I Distribution of immunoreactive material in the brain and pituitary of the sole: $\mathrm{C}$, cerebelfum; MO, medulla oblongata; MT, midbrain tegmentum; $\mathrm{NP}^{\mathrm{P}}$, nucleus praeopticus periventricularis; VOR, nucleus ollactoretinalis; $\mathrm{OB}$, olfactory bulb; ON, optic nerve; OT, optic tectum; P, pituitary gland; rl, lateral recess; rp, posterior recess; $S V$, saccus vasculosus; $T$, telencepha$\operatorname{lon}(\times 6.4) .2 \mathrm{GnRH}$ immunoreactive cell bodies in the caudal part of the olfactory bulb. Longitudinal section $(\times 200) .3$ Immunoreactive neuron in the preoptic area $(\times 560) .4$ GnRH fibers in the anterior part of the pituitary. Longitudinal section: $\mathrm{NH}$, neurohypophysis; ppd, proximal pars distalis $(\times 120) .5$ Longiludinal section of a fascicle of $\mathrm{GnRH}$ fibers above the uptic tract $(\times 400) .6$ GnRH fibers in the retina at the level of the bipolar and amacrinc cells: enl, external nuclear layer; inl, inner nuclear layer; ipl, inner plexiform layer; $\mathrm{pl}$, pigmented layer $(\times 320)$
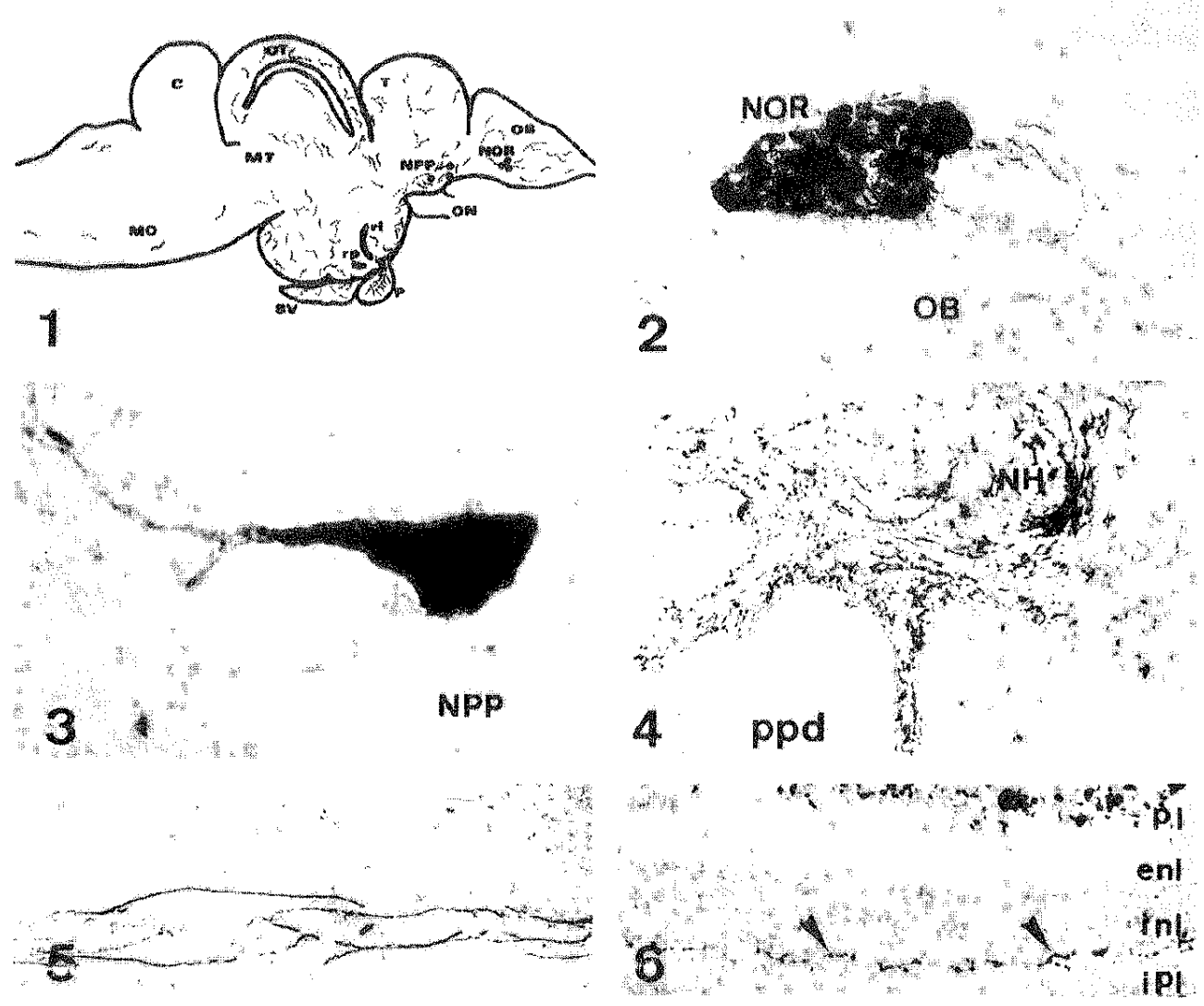
(terminal nerve) which mediates responses to sexual pheromones. The innervation of the retina by fibers of the terminal nerve suggests that the GnRH acts as a transmitter in this retinopetal system ${ }^{10}$. All these data confirm the important role of this system in sexual behaviour as has been described in mammals ${ }^{11}$.

1 Breton, B., Motin, A., Kah, O., Le Menn, F., Geoffre, S., Precigoux (i., and Chambolle, P., C.r. Acad. Sci., Paris 299 (1984) 388.

2 Sherwood, N., Eiden, L., Brownstcin, M., Spiess, I., Rivier, J., and Vale, W., Proc natn. Acad. Sci. USA 80 (1983) 2798

3 Sherwood, N. M., Harvey, B., Brownstein, M.J., and tiden, L. E., Gen. comp. Endocr. 55 (1984) 181

4 Munz, H., Stumpf, W. E., and Jennes, L., Brain Res. 221 (1981) 13

5 Munz, H., Claus, B., Stumpf, W. E., and Jennes, L., Cell Tiss. Res. $222(1982) 323$.

6 Halpern-Sebold, L. R., and Schreibman, M.P., Cell Tiss. Res. 229 (1983) 84 .
The connection of the cell bodies described in the preoptic region with the pituitary gland suggests that this center acts more dim rectly on the gonadotrophic function. Further studies are necessary to determine the relationship between the two centers and the multifunctional actions of GnRH.

7 Schreibman, M.P., Halpern, L. R., Goos, H.J.Th., and Margolis Kazan, H., J. exp. Zool. 210(1979) 160.

8 Kah, O., Chambolle, P., Dubourg, P., and Dubois, M., Gen. comp. Endocr. 53 (1984) 115

9 Demski, L. S., and Northeutt, R. G., Science 220 (1983) 437.

10 Stell, W.K., Walker, S. H., Chohan, K. S., and Ball, A.K., Proc. natn. Acad. Sci. USA 81 (1984) 944.

11 McCann, S. M., A. Rev. Pharmac Toxic. 22 (1982) 515.

$0014-4754 / 85 / 121574-03 \$ 1.50+0.20 / 0$

(C) Birkhäuser Verlag Basel, 1985 